\title{
A Mini-Review of the NADPH Oxidases in Vascular Dementia: Correlation with NOXs and Risk Factors for VaD
}

\author{
Dong-Hee Choi ${ }^{1,2}$ and Jongmin Lee ${ }^{2,3, *}$ \\ 1 Center for Neuroscience Research, Institute of Biomedical Science \& Technology, Konkuk University, \\ 120 Neungdong-ro, Gwangjin-gu, Seoul 143701, Korea; dchoi@kku.ac.kr \\ 2 Department of Medical Science, Konkuk University School of Medicine, 120 Neungdong-ro, Gwangjin-gu, \\ Seoul 143701, Korea \\ 3 Department of Rehabilitation Medicine, Konkuk University School of Medicine, 120 Neungdong-ro, \\ Gwangjin-gu, Seoul 143701, Korea \\ * Correspondence: leej@kuh.ac.kr; Tel.: +82-22030-5345; Fax: +82-2030-7899
}

Received: 30 September 2017; Accepted: 21 November 2017; Published: 22 November 2017

\begin{abstract}
Oxidative stress (OS) is one of the factors that cause dementia conditions such as Alzheimer's disease and vascular dementia $(\mathrm{VaD})$. In the pathogenesis of $\mathrm{VaD}, \mathrm{OS}$ is associated with risk factors that include increased age, hypertension, and stroke. Nicotinamide adenine dinucleotide phosphate (NADPH) oxidases (NOXs) are a molecular source of reactive oxygen species (ROS). According to recent studies, inhibition of NOX activity can reduce cognitive impairment in animal models of VaD. In this article, we review the evidence linking cognitive impairment with NOX-dependent OS, including the vascular NOX and non-vascular NOX systems, in VaD.
\end{abstract}

Keywords: oxidative stress (OS); vascular dementia (VaD); reactive oxygen species (ROS); NADPH oxidases (NOX); cognitive impairment; risk factors

\section{Introduction}

Vascular dementia $(\mathrm{VaD})$ is the second most frequent type of dementia and accounts for $17 \%$ to $25 \%$ of all cases of dementia worldwide [1-3]. It is recognized by the common symptoms of cognitive function decline including reasoning, executive functions, memory, language, perception, and knowledge and cerebrovascular pathologies [4-6]. Although the exact etiopathogenesis of VaD remains unknown, the evidence reported to date seems to indicate that it has multiple causes including cerebrovascular disease and coexisting vascular risk factors such as aging, hypertension, atherosclerosis, and stroke [7-10]. Growing evidence indicates that atherosclerotic pathologies of the vasculature are a hallmark of the development of $\mathrm{VaD}[4]$, and that oxidative stress (OS) plays a causative role in atherosclerosis and other cardiovascular diseases [11]. Many of the risk factors of cerebrovascular disease and $\mathrm{VaD}$ also involve elevated OS [12].

OS imbalances the ratio of antioxidants and reactive oxygen species (ROS) resulting in damage to vessel endothelia, glial and neuronal cells, leading to neurovascular uncoupling and further cerebral blood flow reduction $[6,13]$. The overproduced ROS can destroy mitochondrial function and further induce hypoxia and OS [6,14]. The brain has multiple sources of ROS; however, it has been shown that membrane-bound nicotinamide adenine dinucleotide phosphate (NADPH) oxidase (NOX) enzymes are the primary sources of ROS during aging, hypoperfusion, stroke and hypertension [15]. ROS produced by NOX, which represent a major ROS-generation system, are often associated with the increased OS observed in the VaD and its risk factors [16,17]. Figure 1 shows the risk factors and NOXs of the ROS dependent mechanism for VaD. 


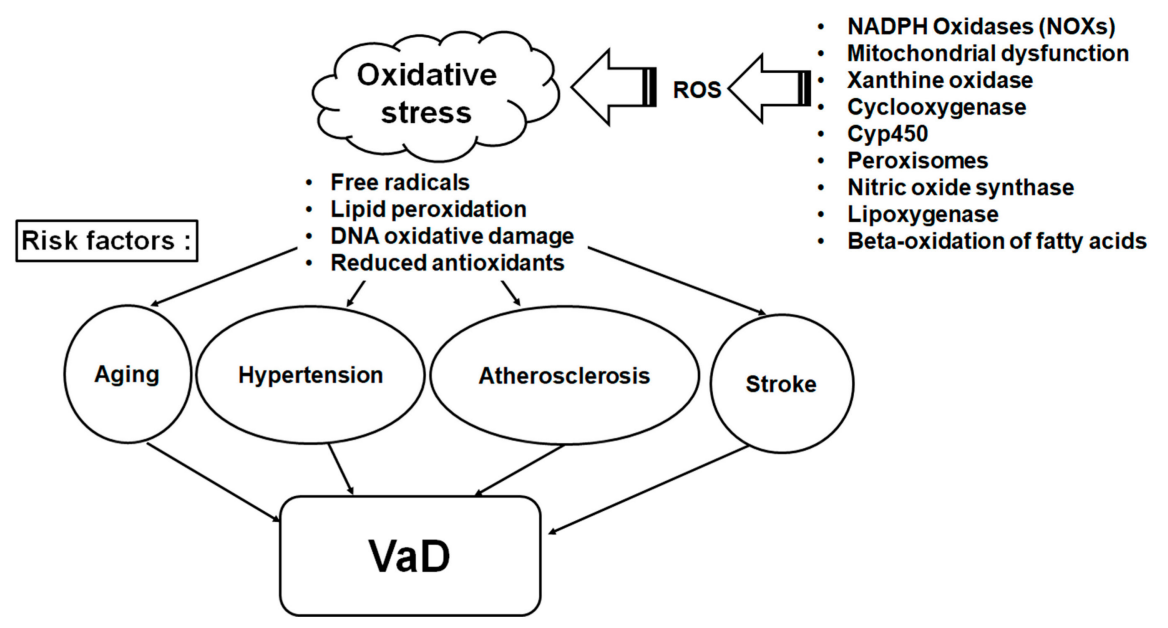

Figure 1. ROS produced by NOX in risk factors for vascular dementia. The open arrows indicate the induction of oxidative stress by ROS producing enzymes. The filled arrows indicate that the oxidative stress affects risk factors for VaD and then induces VaD. VaD: vascular dementia; ROS: reactive oxygen species; NOX: nicotinamide adenine dinucleotide phosphate (NADPH) oxidase.

Recent experimental studies have demonstrated that the inhibition of NOX activity attenuated chronic cerebral hypoperfusion-induced cognitive impairment in a rodent model [18,19]. In this review, we examined the current state of research regarding the roles of NOX in cognitive decline in $\mathrm{VaD}$. In addition to NOX in $\mathrm{VaD}$, we discussed the link between NOX and cognitive impairment in non-vascular cognitive disorders. To determine the association of NOX in cognitive impairment a keyword search on PubMed using the terms "cognitive impairment NADPH oxidase" yielded 76 citations, regardless of the year of publication. Search details of "cognitive impairment NADPH oxidase" was "cognitive dysfunction" or "cognitive" and "dysfunction" or "cognitive dysfunction" or "cognitive" and "impairment" or "cognitive impairment" and "NADPH oxidase" or "NADPH" and "oxidase" or "NADPH oxidase". We excluded 16 review articles, two articles for cell studies, 11 articles included indirect correlation with NOX and cognitive function, and 12 articles with unmeasured cognitive function. We searched the reference lists of articles identified by this search strategy and selected those we judged relevant. Thirty-five publications were selected for this research.

\section{Association between Vascular Dementia (VaD) and Risk Factors and Oxidative Stress (OS)}

In general, the risk factors for $\mathrm{VaD}$ are similar to those reported for cardiovascular disease and stroke. The risk factors for the development of dementia after stroke are multifactorial and contain age rising, vascular risk factors, stroke region, stroke incidence, global brain atrophy, and medical temporal lobe atrophy [20-22]. Comparable risk factors have been determined for VaD without stroke incidence, most notably increasing age and vascular risks, such as high cholesterol, hypertension, and atherosclerosis $[20,23]$.

OS is caused by an environment where imbalance between the production of ROS and removal of ROS by antioxidant species is linked to the pathogenesis of dementia [24]. An enhanced level of ROS in the vasculature, suppressed nitric oxide bioactivities, and abnormal endothelial function resulting to vascular disease, are associated with $\mathrm{VaD}$ [24]. Although studies measuring markers of OS specifically in $\mathrm{VaD}$ are limited, there are data supporting a role for OS in this form of dementia, with most studies performed to date investigating markers of OS in the circulation [24]. Those studies reported a reduction in plasma antioxidant levels [25], elevation of plasma lipid peroxidation [26,27], and increased DNA oxidation in the cerebrospinal fluid [28] of patients with VaD. Regarding OS, it is linked to its risk factors as well as to VaD. Several reports have demonstrated that OS is involved in the pathogenesis of diabetes [29] and hypercholesterolemia [30]. Moreover, it has been reported that 
mitochondrial-induced OS is involved in hypertension-related vasculature damage [31], and that OS is responsible for the oxidation of low-density lipoproteins in atherosclerosis $[32,33]$ and for the high levels of lipid hydroperoxides observed after ischemic stroke [16,34].

\section{NADPH Oxidase in Cerebrovascular Disease}

\subsection{NADPH Oxidase-An Overview}

The family of NAPDH oxidases (NOXs) enzymes is a major source of ROS generation in various tissues [18]. These enzymes are capable of transporting electrons across the plasma membrane and producing superoxide [35]. The phagocytic NOX oxidase (gp91phox or NOX2) was the first identified in phagocytes [36] and is in charge of host defense via the release of considerable amounts of superoxide into phagosomes [18]. Seven NOX isoforms consisting of NOX1, NOX2, NOX3, NOX4, NOX5, dual oxidase (DUOX)1, and DUOX2, have been expressed in a variety of tissues, including brain $[18,37]$.

The NOX and DUOX isoforms have similar binding sites for heme, flavin adenine dinucleotide, and NADPH [38,39] within each isoform and six conserved transmembrane $\alpha$-helices [35]. Both DUOX 1 and DUOX 2 contain an additional transmembrane $\alpha$-helix, followed by a domain that is homologous to peroxidases [35]. The NOX and DUOX enzymes are differentially expressed and their regulation depends on the pathophysiological state of the body and brain [40].

NOX1 and NOX2 assemble with p22phox, and the full activation of p22phox with NOX1 and NOX2 need to bind with other regulatory subunits, p47phox (or its homolog NOX organizer 1, NOXO1), p67phox (or the homologous NOX activator 1, NOXA1), and Ras-related C3 botulinum toxin substrate (Rac) [41-44]. NOX4 has intrinsic activation and affinity with p22phox, but is not essential to other subunits for activation. NOX5 activation is regulated in a calcium-calmodulin-dependent manner, but not need any other subunit $[41,43,44]$.

\subsection{NOX-Dependent Generation of ROS Involves in Cerebrovascular Impairment}

Recently, four isoforms (NOX1, 2, 4, and 5) of NADPH oxidases were discovered in vascular cells and have been shown to play a leading role in various physiological processes, including endothelial function, vascular tone, and vessel generation, as well as in vascular pathological conditions such as hypertension and stroke $[45,46]$. The activity of NOX in cerebral arteries is much higher than it is in the peripheral arteries [46]. Several studies have reported that NOX1, NOX2, and NOX4 manifested in cerebral arteries [47-50]. Kazama et al. reported that the NOX2 protein was expressed in endothelial and adventitial cells of cerebral resistance arteries [50]. Miller et al. found that the NOX4 protein was very highly ( $\geq 10$-fold higher) expressed in rat basilar arteries when compared with the aorta, carotid, and mesenteric arteries [48]. Ago et al. [49] also showed that mRNA for NOX1, NOX2, and NOX4 were expressed in rat basilar endothelial and vascular smooth muscle (VSM) cells. The expression results, ranked in ascending order, are as follows: NOX $2<$ NOX $1<$ NOX 4 . They also demonstrated that the levels of mRNA or protein for NOX1 in endothelial cells were greater than in the VSM cells of basilar arteries [49]. The fine-tuned balance between the NOX-dependent generation of ROS and their detoxification by dismutase enzymes is a very delicate process [45]. The alteration of this balance in disease states result in either an over- or underproduction of ROS induced by vascular damage [45]. Several studies have highlighted the involvement of NOX isoforms in the pathophysiological process of vascular disease [51]. Increased expression of NOX subtypes is determined in various conditions including hypertension [47], insulin resistance [52], diabetes [53,54], and aging [55], ischemic stroke [56], and subarachnoid hemorrhage [57]. In particular, NOX1 and NOX2 have been shown to play deleterious roles [45], whereas NOX4 potentially plays a protective role in vascular diseases such as atherosclerosis [58]. Hence, increasing alteration of NOX expression arises in the status of pathophysiology. Subsequently enhancing of superoxide production would be expected through the increase of NOX activation in variety of disease [51]. 


\section{NADPH Oxidase in Risk Factors for VaD}

\subsection{Increased NOX Expression is Associated with Increasing Age}

Increased NOX activity is related to various cerebrovascular diseases and their risk factors. Cerebrovascular disease is thought to become more common with increasing age as older patients have an increased incidence of ischemic stroke and vascular cognitive impairment affects older persons $[59,60]$. Ali et al. have reported that the increased NOX-derived production of ROS induced learning and memory impairments observed in aged female rats [61]. Resting cerebral blood flow is reduced and cerebral circulation is dysregulated in older individuals [59,62]. These cerebrovascular effects are linked to the enhanced production of ROS in neuronal cells and cerebral vasculature [63]. Park et al. [64] reported that NOX-dependent ROS generated in neurons and blood vessels could involve the cerebrovascular disruption in older mice. Those ROS production and cerebrovascular dysfunction in the brain of 12-month-old mice were reversed by the NOX peptide inhibitor gp91ds-tat [64]. Moreover, the increase in ROS production was not determined in aged NOX2(-/-) mice [64]. Thus, NOX2(-/-) mice are reduced the oxidative stress and cerebrovascular damage induced by advancing age [64]. These findings suggested that NOX2 is a pivotal source of the neurovascular OS that induces the harmful cerebrovascular effects that are associated with increasing age [64].

\subsection{NOX in Hypertension}

The detailed role of vascular NOX oxidases as one of the first pathologies of hypertension has previously been elucidated [65]. Angiotensin II (Ang II) plays a central role via the renin-angiotensin system in the vascular transformation related to hypertension [46], and is an important inducer of increased NOX-dependent superoxide generation in the vascular smooth muscle cells [66] and throughout the cerebral vasculature [67-70]. Ang II induces vascular disease by various mechanisms that lead to ROS-mediated damage and endothelial dysfunction [71]. Ang II is functionally linked to NOX1, NOX2, and diverse to NOX4 in the vasculature [44]. The expression of the catalytic subunits of NOX1, NOX2, and NOX4 and of the p22phox cytosolic subunit are increased by Ang II stimulation $[65,72,73]$. Ang II-activated NOX1 and NOX2 appear to be important in vascular smooth muscle cells (VSMCs) from large and small arteries, respectively, in humans [44,74-76]. Nguyen Dinh Cat et al. demonstrated that NOX4 expression was higher in endothelial cells than in VSMCs, in basal conditions [44]. Activation of NOXs is mediated through the binding of Ang II to the Ang II-angiotensin receptor type 1 [77]. Ang II-mediated NOX activation sequentially produces intracellular $\mathrm{H}_{2} \mathrm{O}_{2}$, which induces vascular hypertrophy [78].

Recent studies have demonstrated that NOX activation participates in the pathogenesis of hypertension and associated vascular dysfunction [79]. NOX2-deficient(-/-) mice do not exhibit cerebrovascular OS and are spared from the alterations in cerebral blood vessels and functional hyperemia induced by Ang II [50,80,81]. Moreover, a peptide that inhibits the gathering of NOX oxidase or a pharmacological inhibitor of this enzyme suppresses the ROS generation and cerebrovascular dysfunction caused by Ang II [80-82]. The detrimental role of NOX1 and NOX2 in the vascular system has been verified in studies of gene-specific deletion or overexpression, whereas the functional importance of NOX4 remains controversial [79]. Schröder et al. have shown that endogenous NOX4 protected the vasculature during femoral artery ligated ischemic stress in animal models $[79,83,84]$. They found that NOX4-deficient animals had angiotensin II-induced hypertrophic and proinflammatory aortic response. Deletion of NOX4 increased inflammatory activation and aortic media hypertrophy in response to angiotensin II and reduced activation of endothelial nitric oxide synthase, nitric oxide production, and the heme oxygenase- 1 (HO-1) system. In contrast, genetic deletion of NOX1 attenuated angiotensin II-induced vascular hypertrophy $[79,83,84]$. However, the protective role of NOX4 may differ from its role in the brain where NOX4 has been shown to contribute to OS and the neurodegeneration linked to stroke and other pathological conditions [79,85]. Therefore, further studies are required to determine the exact role of NOX4 in cerebrovascular diseases. 


\subsection{NOX in Stroke}

There are three major types of stroke: ischemic stroke, subarachnoid hemorrhage (SAH), and intracerebral hemorrhage (ICH) (Table 1) [86]. Both the depletion of oxygen during ischemia and the replenishment of oxygen during reperfusion result in the tissue damage observed in stroke [40]. Ischemia/reperfusion injury is related to increased levels of ROS. OS can arise from increased generation of ROS in the ischemia/reperfusion injury $[87,88]$. There is increasing evidence that NOX-medicated ROS contribute to the pathology that follows cerebral ischemia/reperfusion [35,89-91]. Increased activation of the NOX1 [92], NOX2 [92-95], and NOX4 [85,96] isoforms is involved in ROS production and the development of the pathological condition that follows cerebral ischemia [40]. The expression of NOX1, NOX2, and NOX4 after focal cerebral ischemia was assessed in various cell types, including neurons, astrocytes, and microglia [40]. Remarkably, superoxide production and NOX2 expression have also been shown to be increased in mouse cerebral arteries after focal cerebral ischemia [95]. NOX-oxidase-mediated ROS and Rac1 activation in the hippocampus contributes to cognitive impairment after cerebral ischemia $[97,98]$. Recent studies have suggested that NOX activation is associated with hippocampal cell death and cognitive impairment in rats with cerebral hypoperfusion $[18,19,99]$. A recent study reported that the upregulation of $p 47$ phox oxidase induces spatial memory deficits and hippocampal oxidative DNA damage in chronic intermittent hypoxia conditions [100]. This finding suggests that these factors contribute considerably to cerebral ischemia-induced vascular dysfunction and are risk factors for $\operatorname{VaD}[40,95]$.

There are two types of hemorrhagic stroke: SAH and ICH. SAH is one of the most destructive cerebrovascular diseases [86]. Increased NOX activation has also been associated with the pathology of SAH [40]. Animal studies have reported that elevation of superoxide occurred as early as $12 \mathrm{~h}$ after SAH [57] followed by the enhancement of the expression and activation of NOX2 (gp91phox) [101-103], p47phox [104], and Rac1 [57] in the rat cortex or striatum at $12-48 \mathrm{~h}$ after SAH. The most recent study in this area demonstrated that the levels of the NOX2 and NOX4 proteins were increased in the perilesional neurons and astrocytes in brain tissues from patients with SAH. In an SAH rat model, the NOX2 inhibitor gp91ds-tat and the NOX4 inhibitor GKT137831 decreased SAH-induced neuronal death and degeneration [105].

In a rat model of the other type of hemorrhagic stroke, ICH, the activity of NOX2 increased significantly in the striatum after ICH [103]. Increased expression of gp91phox (NOX2) was mainly observed in activated microglia in ICH-injured brains [106].

These findings indicated that NOX activation has influences the early stage of hemorrhagic stroke and the relatively prolonged stage of ischemic stroke [40].

Table 1. Nicotinamide adenine dinucleotide phosphate (NADPH) oxidases (NOX) expressions in three major types of stroke.

\begin{tabular}{cccc}
\hline Stroke Types & Ischemic Stroke & $\begin{array}{c}\text { Subarachnoid } \\
\text { Hemorrhage }\end{array}$ & $\begin{array}{c}\text { Intracerebral } \\
\text { Hemorrhage }\end{array}$ \\
\hline NOX isoforms & NOX1, NOX2, NOX4 & NOX2, NOX4 & NOX2 \\
\hline Region Cell types & $\begin{array}{c}\text { Cortex, hippocampus, cerebral arteries } \\
\text { Neurons, astrocytes, microglia }\end{array}$ & $\begin{array}{c}\text { Cortex, striatum neurons, } \\
\text { astrocytes }\end{array}$ & Striatum Microglia \\
\hline
\end{tabular}

\section{Association of NADPH Oxidase in Cognitive Impairment}

We focused on the involvement of the NOXs in the cognitive deficits of vascular and non-vascular diseases in this section. Emerging evidence demonstrates that NOX oxidases are involved in the cognitive dysfunction observed in various diseases and in vivo experiments (Table 2).

In cerebrovascular damaged models such as chronic hypoperfusion [18,97-99], cerebral ischemic reperfusion [107], and intermittent hypoxia [108-111] NOX activity and expression of NOX isoforms (NOX1, NOX2, p67phox, and p47phox) increased and cognitive functions were impaired. However, treatment of NOX inhibitor apocynin, ROS scavenger tempol, Rac GTPase inhibitor, downregulation 
of NOX1 mRNA, and gp91phox knockout reversed those impaired cognitive behaviors. Moreover, aged AD-related transgenic mice have increased NOX activities and expressions of NOX2 and NOX4 correlated with cognitive decline. Their mechanisms may involve oxidative stress and deposition of amyloid beta [112-115].

Furthermore, studies on cognitive deficits in non-vascular disease demonstrated that increased NOX2 and p47phox expression and activation was involved in cognitive impairment in traumatic brain injury (TBI) [116-119], various encephalopathies [120-123], and metabolic diseases [13,124,125]. Chandran at al. [116] reported that NOX2 increased and transcription factor Nrf2 that decreased ROS were induced after TBI. The combination therapy (NOX inhibitor apocynin + Nrf2 activator TBHQ) improved cognitive dysfunction in TBI [116]. Di Filippo et al., found that multiple-sclerosis-associated cognitive dysfunction was caused by synaptic dysfunction via a long-term potentiation (LTP) blockade mediated by NOX2 [120]. Ji et al. and Hernandes et al. showed that selective phenotype loss of interneurons mediated by NOX2 activation lead to cognitive impairments in a mouse model of sepsis-associated encephalopathy (SAE) [122,123]. Won et al. [124] confirmed the relationship between cognitive deficits and recurrent hypoglycemia in diabetic rats. They found that NOX-activity dependent oxidative damage and microglial activation increased in the dendritic region of hippocampal CA1 by hypoglycemia in diabetic rat. This study suggests that oxidative injury by hypoglycemia is linked to long term cognitive dysfunction in diabetic patients [124].

More interestingly, Ansari and Scheff showed that the overall NOX enzyme activity level and protein levels of p67phox, p47phox, and p40phox isoforms were elevated in the human postmortem brains of Alzheimer's disease (AD) [126]. Another human study by Bruce-Keller at al. found significant elevations in NOX activity and gp91phox and p47phox expression in the temporal gyri of mild cognitive impairment (MCI) patients when compared with the controls [127]. The increased gp91phox and p47phox expression were shown in the microglia and neurons [127]. Human studies have suggested that an elevated NOX-associated redox pathway might contribute to AD progression [126,127].

Table 2. Experiments of NOX expressions associated cognitive function.

\begin{tabular}{|c|c|c|c|c|}
\hline Disease model & $\begin{array}{l}\text { Increase NOX } \\
\text { isoforms }\end{array}$ & Control of NOX & Mechanism of action & Reference \\
\hline \multirow{2}{*}{$\begin{array}{l}\text { Two-vessel } \\
\text { occlusion rat }\end{array}$} & $\begin{array}{l}\text { gp91phox, } \\
\text { p47phox, } \\
\text { or p67phox }\end{array}$ & Apocynin ${ }^{1}$ & Oxidative stress & [98] \\
\hline & $\begin{array}{l}\text { NOXs activity, } \\
\text { NOX1 }\end{array}$ & Apocynin, shRNA NOX1 AAV & Oxidative stress & [18] \\
\hline \multirow{2}{*}{$\begin{array}{l}\text { bilateral common carotid } \\
\text { artery stenosis mice }\end{array}$} & NOXs activity & Apocynin & Oxidative stress & [107] \\
\hline & p67phox & Tempol $^{2}$ & Oxidative stress & [99] \\
\hline $\begin{array}{l}\text { cerebral ischemic } \\
\text { reperfusion rat }\end{array}$ & NOXs activity & $\begin{array}{l}\text { Rac GTPase inhibitor } \\
\text { (NSC23766) }\end{array}$ & Oxidative stress & [97] \\
\hline $\begin{array}{l}\text { Obstructive sleep apnea, } \\
\text { Long-term exposure to } \\
\text { intermittent hypoxia } \\
\text { (LTIH) mice }\end{array}$ & $\begin{array}{l}\text { NOX2 (gp91phox), } \\
\text { p47phox, p22phox }\end{array}$ & $\begin{array}{c}\text { gp91phox(-/-), erythropoietin, } \\
\text { Apocynin }\end{array}$ & $\begin{array}{l}\text { Lipid peroxidation and } \\
\text { oxidative DNA damage }\end{array}$ & [108-111] \\
\hline Aged Tg2576 Mice & NOXs activity & Apocynin & $\begin{array}{l}\text { Oxidative stress and } \\
\text { cerebrovascular } \\
\text { dysfunction }\end{array}$ & [112] \\
\hline $\begin{array}{l}\text { Aged APP and PS1 } \\
\text { knock-in mice }\end{array}$ & $\begin{array}{l}\text { NOXs activity } \\
\text { NOX } 4\end{array}$ & Young age & Deposition of $A \beta 1-42$ & [113] \\
\hline $\begin{array}{l}\text { Tg2576 and } \\
\text { NOX2(-/-) mice }\end{array}$ & NOX2 & $\begin{array}{l}\text { NOX peptide Inhibitor } \\
\text { gp91ds-tat NOX2(-/-) }\end{array}$ & ROS generation & [114] \\
\hline $\begin{array}{l}\text { gp91phox(-/-) and } \\
\text { IL-6(-/-) aged mice }\end{array}$ & $\begin{array}{l}\text { NOXs activity, } \\
\text { NOX2 }\end{array}$ & $\begin{array}{l}\text { Apocynin, gp91phox(-/-), } \\
\text { IL-6(-/-) }\end{array}$ & Oxidative stress & [115] \\
\hline ACE2KO mice & $\begin{array}{l}\text { p22phox, p40phox, } \\
\text { p67phox, and } \\
\text { gp91phox }\end{array}$ & $\begin{array}{l}\text { angiotensin (Ang)-converting } \\
\text { enzyme (ACE), Tempol }\end{array}$ & Oxidative stress & [128] \\
\hline
\end{tabular}


Table 2. Cont.

\begin{tabular}{|c|c|c|c|c|}
\hline Disease model & $\begin{array}{l}\text { Increase NOX } \\
\text { isoforms }\end{array}$ & Control of NOX & Mechanism of action & Reference \\
\hline $\begin{array}{l}\text { Renin/angiotensinogen } \\
\text { transgenic mice }\end{array}$ & p47phox and Nox4 & Tempol & Oxidative stress & [129] \\
\hline TBI & NOX2 & Apocynin, NOX2(-/-) & ROS formation & [116] \\
\hline $\begin{array}{l}\text { Moderate lateral fluid } \\
\text { percussion injury mice }\end{array}$ & NOXs activity & $\begin{array}{c}\text { bradykinin receptors } \mathrm{B}_{2} \\
\text { antagonist (HOE-140), } \\
\text { Apocynin }\end{array}$ & ROS formation & {$[117,118]$} \\
\hline $\begin{array}{l}\text { Post-traumatic } \\
\text { stress disorder }\end{array}$ & NOX2 & Environmental enrichment & Oxidative stress & [119] \\
\hline $\begin{array}{l}\text { Encephalomyelitis model } \\
\text { of multiple sclerosis }\end{array}$ & NOX2 & Minocycline $^{3}$, apocynin & $\begin{array}{l}\text { hippocampal synaptic } \\
\text { plasticity deficit }\end{array}$ & [120] \\
\hline $\begin{array}{l}\text { Sepsis-associated } \\
\text { encephalopathy }\end{array}$ & NOX2 & Apocynin, gp91phox(-/-) & $\begin{array}{l}\text { Inflammation and } \\
\text { oxidative stress }\end{array}$ & {$[122,123]$} \\
\hline $\begin{array}{l}\text { Recurrent/moderate } \\
\text { hypoglycemia rat }\end{array}$ & NOXs activity & Apocynin & Oxidative damage & [124] \\
\hline $\begin{array}{l}\text { Streptozotocin diabetes } \\
\text { induced vascular } \\
\text { dementia in rats }\end{array}$ & NOXs activity & $\begin{array}{l}\text { NOX inhibitor, } 4^{\prime} \text {-hydroxy- } \\
3^{\prime} \text {-methoxyacetophenone }\end{array}$ & Oxidative stress & [130] \\
\hline $\begin{array}{c}\text { Endoplasmic reticulum } \\
\text { stress, domoic } \\
\text { acid-treated mice }\end{array}$ & $\begin{array}{l}\text { p47phox and } \\
\text { gp91phox }\end{array}$ & estrogen receptor- $\alpha$ & ROS formation, ER stress & [131] \\
\hline $\begin{array}{l}\text { Sleep fragmentation } \\
\text { in mice }\end{array}$ & gp91phox & gp91phox(-/-) mice & $\begin{array}{l}\text { Lipid peroxidation and } \\
\text { oxidative DNA damage }\end{array}$ & [132] \\
\hline Postoperative aging mice & NOX2 & Apocynin, & Oxidative stress & {$[133,134]$} \\
\hline $\begin{array}{l}\text { p47phox and nNOS double } \\
\text { KO mice }\end{array}$ & p47phox & p47phox(-/-)and nNOS(-/-) & ROS and NO formation & [138] \\
\hline AD postmortem brains & $\begin{array}{l}\text { p67phox, p47phox, } \\
\text { and p40phox }\end{array}$ & & $\begin{array}{c}\text { Increasing of redox } \\
\text { pathways }\end{array}$ & [126] \\
\hline MCI postmortem brains & $\begin{array}{l}\text { NOXs activity, } \\
\text { gp91phox, } \\
\text { p47phox }\end{array}$ & & Microglia activation & {$[127]$} \\
\hline
\end{tabular}

${ }^{1}$ NOX inhibitor, Apocynin; ${ }^{2}$ ROS scavengers, Tempol; ${ }^{3}$ Minocycline, antibiotic. MCI: mild cognitive impairment; KO: knockout; ACE: angiotensin (Ang)-converting enzyme.

\section{Conclusions}

VaD can result from a loss of brain cells induced by hypoperfusion via damage to the vascular system. The factors that can cause vascular damage in VaD include aging, hypertension, and stroke. NOX oxidases play a role as a major ROS generator in cerebrovascular and neurodegenerative diseases. NOX-mediated ROS induce neuroinflammation and OS in blood vessels in conditions of aging, hypertension, and stroke. Moreover, NOX activation has also been linked to cognitive impairment in various neurological disorders. In this review, we summarized the current research regarding the association between risk factors for VaD and NOX: (1) Increased NOX expression was associated with the aging risk factor; (2) NOX activation produced intracellular $\mathrm{H}_{2} \mathrm{O}_{2}$, which induced vascular hypertrophy as a hypertension risk factor; (3) Increased activation of the NOX1, NOX2, and NOX4 isoforms was involved in ROS production and the development of the pathological condition in stroke risk factor; and (4) NOXs associated cognitive impairment was involved not only in vascular dementia but also in non-vascular diseases. 
Considering the relationship between NOX and the risk factors for VaD (including aging, hypertension, and stroke), we suggest that further studies are necessary to examine the different roles of the vascular NOX isoforms and neuronal NOX isoforms in VaD. Moreover, we emphasize the contention that the regulation of NOX levels in cerebral vessels and the modulation of NOX activation in neurons and glial cells are important for the prevention and treatment of $\mathrm{VaD}$.

Therefore, regulation of NOX may serve as a potential therapeutic target for VaD. Furthermore, emerging translational studies for controlling the risk factors through NOX regulation in VaD may have serious impacts on the significance of clinical application.

Acknowledgments: This research was supported by Basic Science Research Program through the National Research Foundation of Korea (NRF) funded by the Ministry of Science, Information and Communications Technology (ICT) and Future Planning (NRF-2014R1A2A1A11050236 grant to DHC, NRF-2014R1A2A1A11050248 and NRF-2017R1A2B4004837 grant to JL); a grant from the Korea Health Technology R\&D Project through the Korea Health Industry Development Institute (KHIDI), funded by the Ministry of Health \& Welfare, Republic of Korea (grant number: HI14C2339); and the National Research Foundation of Korea (NRF) grant funded by the Korean government (NRF-2016R1A5A2012284).

Author Contributions: Dong-Hee Choi and Jongmin Lee conceived this review and drafted the manuscript. Dong-Hee Choi projected and designed the schematic picture. All authors reviewed and approved the submitted manuscript.

Conflicts of Interest: The authors declare no conflict of interest.

\section{Abbreviations}

NADPH Nicotinamide adenine dinucleotide phosphate

OS Oxidative stress

VaD Vascular dementia

ROS Reactive oxygen species

NOX NADPH oxidase

phox Phagocytic oxidase

DUOX Dual oxidase

NOXO1 NOX organizer 1

NOXA1 NOX activator 1

Rac Ras-related C3 botulinum toxin substrate

Ang II Angiotensin II

$\mathrm{SAH}$ Subarachnoid hemorrhage

$\mathrm{ICH}$ Intracerebral hemorrhage

CA1 Cornu Ammonis 1

ACE Angiotensin (Ang)-converting enzyme

IL-6 Interleukin-6

nNOS Neuronal nitric oxide synthase

TBI Traumatic brain injury

TBHQ Tertiary Butylhydroquinone

LTP Long-term potentiation

SAE Sepsis-associated encephalopathy

AD Alzheimer's disease

KO Knockout

Nrf2 NF-E2-related factor-2 


\section{References}

1. McGuinness, B.; Craig, D.; Bullock, R.; Passmore, P. Statins for the prevention of dementia. Cochrane Database Syst. Rev. 2016, 1, CD003160.

2. Gorelick, P.B.; Scuteri, A.; Black, S.E.; Decarli, C.; Greenberg, S.M.; Iadecola, C.; Launer, L.J.; Laurent, S.; Lopez, O.L.; Nyenhuis, D.; et al. Vascular contributions to cognitive impairment and dementia: A statement for healthcare professionals from the american heart association/american stroke association. Stroke 2011, 42, 2672-2713. [CrossRef] [PubMed]

3. Appleton, J.P.; Scutt, P.; Sprigg, N.; Bath, P.M. Hypercholesterolaemia and vascular dementia. Clin. Sci. 2017, 131, 1561-1578. [CrossRef] [PubMed]

4. Van Oijen, M.; de Jong, F.J.; Witteman, J.C.; Hofman, A.; Koudstaal, P.J.; Breteler, M.M. Atherosclerosis and risk for dementia. Ann. Neurol. 2007, 61, 403-410. [CrossRef] [PubMed]

5. Song, J.; Lee, W.T.; Park, K.A.; Lee, J.E. Association between risk factors for vascular dementia and adiponectin. Biomed. Res. Int. 2014, 2014, 261672. [CrossRef] [PubMed]

6. Venkat, P.; Chopp, M.; Chen, J. Models and mechanisms of vascular dementia. Exp. Neurol. 2015, 272, 97-108. [CrossRef] [PubMed]

7. Craft, S. The role of metabolic disorders in alzheimer disease and vascular dementia: Two roads converged. Arch. Neurol. 2009, 66, 300-305. [CrossRef] [PubMed]

8. Fillit, H.; Nash, D.T.; Rundek, T.; Zuckerman, A. Cardiovascular risk factors and dementia. Am. J. Geriatr. Pharmacother. 2008, 6, 100-118. [CrossRef] [PubMed]

9. Honjo, K.; Black, S.E.; Verhoeff, N.P. Alzheimer's disease, cerebrovascular disease, and the $\beta$-amyloid cascade. Can. J. Neurol. Sci. 2012, 39, 712-728. [CrossRef] [PubMed]

10. Purnell, C.; Gao, S.; Callahan, C.M.; Hendrie, H.C. Cardiovascular risk factors and incident alzheimer disease: A systematic review of the literature. Alzheimer Dis. Assoc. Disord. 2009, 23, 1-10. [CrossRef] [PubMed]

11. Singh, U.; Jialal, I. Oxidative stress and atherosclerosis. Pathophysiology 2006, 13, 129-142. [CrossRef] [PubMed]

12. Li, H.; Horke, S.; Forstermann, U. Vascular oxidative stress, nitric oxide and atherosclerosis. Atherosclerosis 2014, 237, 208-219. [CrossRef] [PubMed]

13. Liu, H.; Zhang, J. Cerebral hypoperfusion and cognitive impairment: The pathogenic role of vascular oxidative stress. Int. J. Neurosci. 2012, 122, 494-499. [CrossRef] [PubMed]

14. Zhang, X.; Wu, B.; Nie, K.; Jia, Y.; Yu, J. Effects of acupuncture on declined cerebral blood flow, impaired mitochondrial respiratory function and oxidative stress in multi-infarct dementia rats. Neurochem. Int. 2014, 65, 23-29. [CrossRef] [PubMed]

15. Drummond, G.R.; Selemidis, S.; Griendling, K.K.; Sobey, C.G. Combating oxidative stress in vascular disease: NADPH oxidases as therapeutic targets. Nat. Rev. Drug. Discov. 2011, 10, 453-471. [CrossRef] [PubMed]

16. Luca, M.; Luca, A.; Calandra, C. The role of oxidative damage in the pathogenesis and progression of alzheimer's disease and vascular dementia. Oxid. Med. Cell. Longev. 2015, 2015, 504678. [CrossRef] [PubMed]

17. Zekry, D.; Epperson, T.K.; Krause, K.H. A role for nox nadph oxidases in alzheimer's disease and other types of dementia? IUBMB Life 2003, 55, 307-313. [CrossRef] [PubMed]

18. Choi, D.H.; Lee, K.H.; Kim, J.H.; Seo, J.H.; Kim, H.Y.; Shin, C.Y.; Han, J.S.; Han, S.H.; Kim, Y.S.; Lee, J. Nadph oxidase 1, a novel molecular source of ROS in hippocampal neuronal death in vascular dementia. Antioxid. Redox. Signal. 2014, 21, 533-550. [CrossRef] [PubMed]

19. Kim, H.A.; Miller, A.A.; Drummond, G.R.; Thrift, A.G.; Arumugam, T.V.; Phan, T.G.; Srikanth, V.K.; Sobey, C.G. Vascular cognitive impairment and alzheimer's disease: Role of cerebral hypoperfusion and oxidative stress. N-S Arch. Pharmacol. 2012, 385, 953-959. [CrossRef] [PubMed]

20. O'Brien, J.T.; Thomas, A. Vascular dementia. Lancet 2015, 386, 1698-1706. [CrossRef]

21. Cervellati, C.; Romani, A.; Seripa, D.; Cremonini, E.; Bosi, C.; Magon, S.; Passaro, A.; Bergamini, C.M.; Pilotto, A.; Zuliani, G. Oxidative balance, homocysteine, and uric acid levels in older patients with late onset alzheimer's disease or vascular dementia. J. Neurol. Sci. 2014, 337, 156-161. [CrossRef] [PubMed]

22. Yang, J.; Wong, A.; Wang, Z.; Liu, W.; Au, L.; Xiong, Y.; Chu, W.W.; Leung, E.Y.; Chen, S.; Lau, C.; et al. Risk factors for incident dementia after stroke and transient ischemic attack. Alzheimers Dement. 2015, 11, 16-23. [CrossRef] [PubMed] 
23. Wiesmann, M.; Kiliaan, A.J.; Claassen, J.A. Vascular aspects of cognitive impairment and dementia. J. Cereb. Blood Flow. Metab. 2013, 33, 1696-1706. [CrossRef] [PubMed]

24. Bennett, S.; Grant, M.M.; Aldred, S. Oxidative stress in vascular dementia and alzheimer's disease: A common pathology. J. Alzheimers Dis. 2009, 17, 245-257. [CrossRef] [PubMed]

25. Polidori, M.C.; Mattioli, P.; Aldred, S.; Cecchetti, R.; Stahl, W.; Griffiths, H.; Senin, U.; Sies, H.; Mecocci, P. Plasma antioxidant status, immunoglobulin g oxidation and lipid peroxidation in demented patients: Relevance to alzheimer disease and vascular dementia. Dement. Geriatr. Cogn. Disord. 2004, 18, 265-270. [CrossRef] [PubMed]

26. Casado, A.; Encarnacion Lopez-Fernandez, M.; Concepcion Casado, M.; de La Torre, R. Lipid peroxidation and antioxidant enzyme activities in vascular and alzheimer dementias. Neurochem. Res. 2008, 33, 450-458. [CrossRef] [PubMed]

27. Gustaw-Rothenberg, K.; Kowalczuk, K.; Stryjecka-Zimmer, M. Lipids' peroxidation markers in alzheimer's disease and vascular dementia. Geriatr. Gerontol. Int. 2010, 10, 161-166. [CrossRef] [PubMed]

28. Gackowski, D.; Rozalski, R.; Siomek, A.; Dziaman, T.; Nicpon, K.; Klimarczyk, M.; Araszkiewicz, A.; Olinski, R. Oxidative stress and oxidative DNA damage is characteristic for mixed alzheimer disease/vascular dementia. J. Neurol. Sci. 2008, 266, 57-62. [CrossRef] [PubMed]

29. Maritim, A.C.; Sanders, R.A.; Watkins, J.B., 3rd. Diabetes, oxidative stress, and antioxidants: A review. J. Biochem. Mol. Toxicol. 2003, 17, 24-38. [CrossRef] [PubMed]

30. Dias, I.H.; Polidori, M.C.; Griffiths, H.R. Hypercholesterolaemia-induced oxidative stress at the blood-brain barrier. Biochem. Soc. Trans. 2014, 42, 1001-1005. [CrossRef] [PubMed]

31. Rubattu, S.; Pagliaro, B.; Pierelli, G.; Santolamazza, C.; Castro, S.D.; Mennuni, S.; Volpe, M. Pathogenesis of target organ damage in hypertension: Role of mitochondrial oxidative stress. Int. J. Mol. Sci. 2014, 16, 823-839. [CrossRef] [PubMed]

32. Oliveira, H.C.; Cosso, R.G.; Alberici, L.C.; Maciel, E.N.; Salerno, A.G.; Dorighello, G.G.; Velho, J.A.; de Faria, E.C.; Vercesi, A.E. Oxidative stress in atherosclerosis-prone mouse is due to low antioxidant capacity of mitochondria. FASEB J. 2005, 19, 278-280. [CrossRef] [PubMed]

33. Luc, G.; Fruchart, J.C. Oxidation of lipoproteins and atherosclerosis. Am. J. Clin. Nutr. 1991, 53, 206 S-209S. [PubMed]

34. Polidori, M.C.; Frei, B.; Cherubini, A.; Nelles, G.; Rordorf, G.; Keaney, J.F., Jr.; Schwamm, L.; Mecocci, P.; Koroshetz, W.J.; Beal, M.F. Increased plasma levels of lipid hydroperoxides in patients with ischemic stroke. Free Radic. Biol. Med. 1998, 25, 561-567. [CrossRef]

35. Bedard, K.; Krause, K.H. The NOX family of ROS-generating nadph oxidases: Physiology and pathophysiology. Physiol. Rev. 2007, 87, 245-313. [CrossRef] [PubMed]

36. Rossi, F.; Zatti, M. Biochemical aspects of phagocytosis in polymorphonuclear leucocytes. Nadh and nadph oxidation by the granules of resting and phagocytizing cells. Experientia 1964, 20, 21-23. [CrossRef] [PubMed]

37. Cheng, G.; Cao, Z.; Xu, X.; van Meir, E.G.; Lambeth, J.D. Homologs of gp91phox: Cloning and tissue expression of nox3, nox4, and nox5. Gene 2001, 269, 131-140. [CrossRef]

38. Geiszt, M.; Leto, T.L. The Nox family of NAD(P)H oxidases: Host defense and beyond. J. Biol. Chem. 2004, 279, 51715-51718. [CrossRef] [PubMed]

39. Pendyala, S.; Natarajan, V. Redox regulation of Nox proteins. Respir. Physiol. Neurobiol. 2010, 174, $265-271$. [CrossRef] [PubMed]

40. Ma, M.W.; Wang, J.; Zhang, Q.; Wang, R.; Dhandapani, K.M.; Vadlamudi, R.K.; Brann, D.W. NADPH oxidase in brain injury and neurodegenerative disorders. Mol. Neurodegener. 2017, 12, 7. [CrossRef] [PubMed]

41. Dutta, S.; Rittinger, K. Regulation of NOXO1 activity through reversible interactions with p22 and NOXA1. PLoS ONE 2010, 5, e10478. [CrossRef] [PubMed]

42. Leto, T.L.; Morand, S.; Hurt, D.; Ueyama, T. Targeting and regulation of reactive oxygen species generation by Nox family NADPH oxidases. Antioxid. Redox. Signal. 2009, 11, 2607-2619. [CrossRef] [PubMed]

43. Streeter, J.; Thiel, W.; Brieger, K.; Miller, F.J., Jr. Opportunity Nox: The future of NADPH oxidases as therapeutic targets in cardiovascular disease. Cardiovasc. Ther. 2013, 31, 125-137. [CrossRef] [PubMed]

44. Nguyen Dinh Cat, A.; Montezano, A.C.; Burger, D.; Touyz, R.M. Angiotensin II, NADPH oxidase, and redox signaling in the vasculature. Antioxid. Redox. Signal. 2013, 19, 1110-1120. [CrossRef] [PubMed]

45. Gray, S.P.; Jandeleit-Dahm, K.A. The role of NADPH oxidase in vascular disease-Hypertension, atherosclerosis \& stroke. Curr. Pharm. Des. 2015, 21, 5933-5944. [PubMed] 
46. Miller, A.A.; Drummond, G.R.; Sobey, C.G. Novel isoforms of NADPH-oxidase in cerebral vascular control. Pharmacol. Ther. 2006, 111, 928-948. [CrossRef] [PubMed]

47. Paravicini, T.M.; Chrissobolis, S.; Drummond, G.R.; Sobey, C.G. Increased NADPH-oxidase activity and Nox4 expression during chronic hypertension is associated with enhanced cerebral vasodilatation to NADPH in vivo. Stroke 2004, 35, 584-589. [CrossRef] [PubMed]

48. Miller, A.A.; Drummond, G.R.; Schmidt, H.H.; Sobey, C.G. NADPH oxidase activity and function are profoundly greater in cerebral versus systemic arteries. Circ. Res. 2005, 97, 1055-1062. [CrossRef] [PubMed]

49. Ago, T.; Kitazono, T.; Kuroda, J.; Kumai, Y.; Kamouchi, M.; Ooboshi, H.; Wakisaka, M.; Kawahara, T.; Rokutan, K.; Ibayashi, S.; et al. NAD(P)H oxidases in rat basilar arterial endothelial cells. Stroke 2005, 36, 1040-1046. [CrossRef] [PubMed]

50. Kazama, K.; Anrather, J.; Zhou, P.; Girouard, H.; Frys, K.; Milner, T.A.; Iadecola, C. Angiotensin II impairs neurovascular coupling in neocortex through NADPH oxidase-derived radicals. Circ. Res. 2004, 95, 1019-1026. [CrossRef] [PubMed]

51. Chrissobolis, S.; Faraci, F.M. The role of oxidative stress and NADPH oxidase in cerebrovascular disease. Trends Mol. Med. 2008, 14, 495-502. [CrossRef] [PubMed]

52. Erdos, B.; Snipes, J.A.; Tulbert, C.D.; Katakam, P.; Miller, A.W.; Busija, D.W. Rosuvastatin improves cerebrovascular function in zucker obese rats by inhibiting $\mathrm{NAD}(\mathrm{P}) \mathrm{H}$ oxidase-dependent superoxide production. Am. J. Physiol. Heart Circ. Physiol. 2006, 290, H1264-1270. [CrossRef] [PubMed]

53. Matsumoto, T.; Kobayashi, T.; Wachi, H.; Seyama, Y.; Kamata, K. Vascular NAD(P)H oxidase mediates endothelial dysfunction in basilar arteries from Otsuka long-evans tokushima fatty (OLETF) rats. Atherosclerosis 2007, 192, 15-24. [CrossRef] [PubMed]

54. Mayhan, W.G.; Arrick, D.M.; Sharpe, G.M.; Patel, K.P.; Sun, H. Inhibition of NAD(P)H oxidase alleviates impaired NOS-dependent responses of pial arterioles in type 1 diabetes mellitus. Microcirculation 2006, 13, 567-575. [CrossRef] [PubMed]

55. Mayhan, W.G.; Arrick, D.M.; Sharpe, G.M.; Sun, H. Age-related alterations in reactivity of cerebral arterioles: Role of oxidative stress. Microcirculation 2008, 15, 225-236. [CrossRef] [PubMed]

56. Vallet, P.; Charnay, Y.; Steger, K.; Ogier-Denis, E.; Kovari, E.; Herrmann, F.; Michel, J.P.; Szanto, I. Neuronal expression of the NADPH oxidase nox4, and its regulation in mouse experimental brain ischemia. Neuroscience 2005, 132, 233-238. [CrossRef] [PubMed]

57. Shin, H.K.; Lee, J.H.; Kim, K.Y.; Kim, C.D.; Lee, W.S.; Rhim, B.Y.; Hong, K.W. Impairment of autoregulatory vasodilation by $\mathrm{NAD}(\mathrm{P}) \mathrm{H}$ oxidase-dependent superoxide generation during acute stage of subarachnoid hemorrhage in rat pial artery. J. Cereb. Blood Flow. Metab. 2002, 22, 869-877. [CrossRef] [PubMed]

58. Gray, S.P.; Di Marco, E.; Kennedy, K.; Chew, P.; Okabe, J.; El-Osta, A.; Calkin, A.C.; Biessen, E.A.; Touyz, R.M.; Cooper, M.E.; et al. Reactive oxygen species can provide atheroprotection via NOX4-dependent inhibition of inflammation and vascular remodeling. Arterioscler. Thromb. Vasc. Biol. 2016, 36, 295-307. [CrossRef] [PubMed]

59. Farkas, E.; Luiten, P.G. Cerebral microvascular pathology in aging and alzheimer's disease. Prog. Neurobiol. 2001, 64, 575-611. [CrossRef]

60. Rothwell, P.M.; Coull, A.J.; Silver, L.E.; Fairhead, J.F.; Giles, M.F.; Lovelock, C.E.; Redgrave, J.N.; Bull, L.M.; Welch, S.J.; Cuthbertson, F.C.; et al. Population-based study of event-rate, incidence, case fatality, and mortality for all acute vascular events in all arterial territories (oxford vascular study). Lancet 2005, 366, 1773-1783. [CrossRef]

61. Ali, S.S.; Young, J.W.; Wallace, C.K.; Gresack, J.; Jeste, D.V.; Geyer, M.A.; Dugan, L.L.; Risbrough, V.B. Initial evidence linking synaptic superoxide production with poor short-term memory in aged mice. Brain Res. 2011, 1368, 65-70. [CrossRef] [PubMed]

62. Faraci, F.M. Reactive oxygen species: Influence on cerebral vascular tone. J. Appl. Physiol. 2006, 100, 739-743. [CrossRef] [PubMed]

63. Park, L.; Koizumi, K.; El Jamal, S.; Zhou, P.; Previti, M.L.; Van Nostrand, W.E.; Carlson, G.; Iadecola, C. Age-dependent neurovascular dysfunction and damage in a mouse model of cerebral amyloid angiopathy. Stroke 2014, 45, 1815-1821. [CrossRef] [PubMed]

64. Park, L.; Anrather, J.; Girouard, H.; Zhou, P.; Iadecola, C. Nox2-derived reactive oxygen species mediate neurovascular dysregulation in the aging mouse brain. J. Cereb. Blood Flow. Metab. 2007, 27, 1908-1918. [CrossRef] [PubMed] 
65. Rajagopalan, S.; Kurz, S.; Munzel, T.; Tarpey, M.; Freeman, B.A.; Griendling, K.K.; Harrison, D.G. Angiotensin II-mediated hypertension in the rat increases vascular superoxide production via membrane NADH/NADPH oxidase activation. Contribution to alterations of vasomotor tone. J. Clin. Investig. 1996, 97, 1916-1923. [CrossRef] [PubMed]

66. Ding, L.; Chapman, A.; Boyd, R.; Wang, H.D. ERK activation contributes to regulation of spontaneous contractile tone via superoxide anion in isolated rat aorta of angiotensin II-induced hypertension. Am. J. Physiol. Heart Circ. Physiol. 2007, 292, H2997-3005. [CrossRef] [PubMed]

67. Nakane, H.; Miller, F.J., Jr.; Faraci, F.M.; Toyoda, K.; Heistad, D.D. Gene transfer of endothelial nitric oxide synthase reduces angiotensin II-induced endothelial dysfunction. Hypertension 2000, 35, 595-601. [CrossRef] [PubMed]

68. Faraci, F.M.; Lamping, K.G.; Modrick, M.L.; Ryan, M.J.; Sigmund, C.D.; Didion, S.P. Cerebral vascular effects of angiotensin II: New insights from genetic models. J. Cereb. Blood Flow. Metab. 2006, 26, 449-455. [CrossRef] [PubMed]

69. Chu, Y.; Alwahdani, A.; Iida, S.; Lund, D.D.; Faraci, F.M.; Heistad, D.D. Vascular effects of the human extracellular superoxide dismutase R213G variant. Circulation 2005, 112, 1047-1053. [CrossRef] [PubMed]

70. Feldberg, W.; Myers, R.D.; Veale, W.L. Perfusion from cerebral ventricle to cisterna magna in the unanaesthetized cat. Effect of calcium on body temperature. J. Physiol. 1970, 207, 403-416. [CrossRef] [PubMed]

71. Chrissobolis, S.; Banfi, B.; Sobey, C.G.; Faraci, F.M. Role of Nox isoforms in angiotensin II-induced oxidative stress and endothelial dysfunction in brain. J. Appl. Physiol. 2012, 113, 184-191. [CrossRef] [PubMed]

72. Chabrashvili, T.; Kitiyakara, C.; Blau, J.; Karber, A.; Aslam, S.; Welch, W.J.; Wilcox, C.S. Effects of ANG II type 1 and 2 receptors on oxidative stress, renal NADPH oxidase, and SOD expression. Am. J. Physiol. Regul. Integr. Comp. Physiol. 2003, 285, R117-124. [CrossRef] [PubMed]

73. Matsuno, K.; Yamada, H.; Iwata, K.; Jin, D.; Katsuyama, M.; Matsuki, M.; Takai, S.; Yamanishi, K.; Miyazaki, M.; Matsubara, H.; et al. Nox1 is involved in angiotensin II-mediated hypertension: A study in Nox1-deficient mice. Circulation 2005, 112, 2677-2685. [CrossRef] [PubMed]

74. Griendling, K.K.; Minieri, C.A.; Ollerenshaw, J.D.; Alexander, R.W. Angiotensin II stimulates NADH and NADPH oxidase activity in cultured vascular smooth muscle cells. Circ. Res. 1994, 74, 1141-1148. [CrossRef] [PubMed]

75. Touyz, R.M.; Chen, X.; Tabet, F.; Yao, G.; He, G.; Quinn, M.T.; Pagano, P.J.; Schiffrin, E.L. Expression of a functionally active gp91phox-containing neutrophil-type NAD(P)H oxidase in smooth muscle cells from human resistance arteries: Regulation by angiotensin II. Circ. Res. 2002, 90, 1205-1213. [CrossRef] [PubMed]

76. Ushio-Fukai, M.; Zafari, A.M.; Fukui, T.; Ishizaka, N.; Griendling, K.K. P22phox is a critical component of the superoxide-generating NADH/NADPH oxidase system and regulates angiotensin II-induced hypertrophy in vascular smooth muscle cells. J. Biol. Chem. 1996, 271, 23317-23321. [CrossRef] [PubMed]

77. Guzik, T.J.; Sadowski, J.; Guzik, B.; Jopek, A.; Kapelak, B.; Przybylowski, P.; Wierzbicki, K.; Korbut, R.; Harrison, D.G.; Channon, K.M. Coronary artery superoxide production and nox isoform expression in human coronary artery disease. Arterioscler. Thromb. Vasc. Biol. 2006, 26, 333-339. [CrossRef] [PubMed]

78. Zafari, A.M.; Ushio-Fukai, M.; Akers, M.; Yin, Q.; Shah, A.; Harrison, D.G.; Taylor, W.R.; Griendling, K.K. Role of NADH/NADPH oxidase-derived $\mathrm{H} 2 \mathrm{O} 2$ in angiotensin II-induced vascular hypertrophy. Hypertension 1998, 32, 488-495. [CrossRef] [PubMed]

79. Konior, A.; Schramm, A.; Czesnikiewicz-Guzik, M.; Guzik, T.J. NADPH oxidases in vascular pathology. Antioxid. Redox. Signal. 2014, 20, 2794-2814. [CrossRef] [PubMed]

80. Girouard, H.; Park, L.; Anrather, J.; Zhou, P.; Iadecola, C. Angiotensin II attenuates endothelium-dependent responses in the cerebral microcirculation through Nox-2-derived radicals. Arterioscler. Thromb. Vasc. Biol. 2006, 26, 826-832. [CrossRef] [PubMed]

81. Iadecola, C.; Davisson, R.L. Hypertension and cerebrovascular dysfunction. Cell Metab. 2008, 7, $476-484$. [CrossRef] [PubMed]

82. Didion, S.P.; Faraci, F.M. Angiotensin II produces superoxide-mediated impairment of endothelial function in cerebral arterioles. Stroke 2003, 34, 2038-2042. [CrossRef] [PubMed]

83. Brandes, R.P.; Takac, I.; Schroder, K. No superoxide-No stress?: Nox4, the good NADPH oxidase! Arterioscler. Thromb. Vasc. Biol. 2011, 31, 1255-1257. [CrossRef] [PubMed] 
84. Schroder, K.; Zhang, M.; Benkhoff, S.; Mieth, A.; Pliquett, R.; Kosowski, J.; Kruse, C.; Luedike, P.; Michaelis, U.R.; Weissmann, N.; et al. Nox4 is a protective reactive oxygen species generating vascular NADPH oxidase. Circ. Res. 2012, 110, 1217-1225. [CrossRef] [PubMed]

85. Kleinschnitz, C.; Grund, H.; Wingler, K.; Armitage, M.E.; Jones, E.; Mittal, M.; Barit, D.; Schwarz, T.; Geis, C.; Kraft, P.; et al. Post-stroke inhibition of induced NADPH oxidase type 4 prevents oxidative stress and neurodegeneration. PLoS Biol. 2010, 8, e1000479. [CrossRef] [PubMed]

86. Zhang, L.; Wu, J.; Duan, X.; Tian, X.; Shen, H.; Sun, Q.; Chen, G. NADPH oxidase: A potential target for treatment of stroke. Oxid. Med. Cell. Longev. 2016, 2016, 5026984. [CrossRef] [PubMed]

87. Chen, H.; Yoshioka, H.; Kim, G.S.; Jung, J.E.; Okami, N.; Sakata, H.; Maier, C.M.; Narasimhan, P.; Goeders, C.E.; Chan, P.H. Oxidative stress in ischemic brain damage: Mechanisms of cell death and potential molecular targets for neuroprotection. Antioxid. Redox. Signal. 2011, 14, 1505-1517. [CrossRef] [PubMed]

88. Chan, P.H. Reactive oxygen radicals in signaling and damage in the ischemic brain. J. Cereb. Blood Flow. Metab. 2001, 21, 2-14. [CrossRef] [PubMed]

89. Chen, H.; Song, Y.S.; Chan, P.H. Inhibition of NADPH oxidase is neuroprotective after ischemia-reperfusion. J. Cereb. Blood Flow. Metab. 2009, 29, 1262-1272. [CrossRef] [PubMed]

90. Zhang, Q.G.; Raz, L.; Wang, R.; Han, D.; De Sevilla, L.; Yang, F.; Vadlamudi, R.K.; Brann, D.W. Estrogen attenuates ischemic oxidative damage via an ER $\alpha$-mediated inhibition of NADPH oxidase activation. J. Neurosci. 2009, 29, 13823-13836. [CrossRef] [PubMed]

91. Zhang, Q.G.; Laird, M.D.; Han, D.; Nguyen, K.; Scott, E.; Dong, Y.; Dhandapani, K.M.; Brann, D.W. Critical role of NADPH oxidase in neuronal oxidative damage and microglia activation following traumatic brain injury. PLoS ONE 2012, 7, e34504. [CrossRef] [PubMed]

92. Choi, D.H.; Kim, J.H.; Lee, K.H.; Kim, H.Y.; Kim, Y.S.; Choi, W.S.; Lee, J. Role of neuronal NADPH oxidase 1 in the peri-infarct regions after stroke. PLoS ONE 2015, 10, e0116814. [CrossRef] [PubMed]

93. Yoshioka, H.; Niizuma, K.; Katsu, M.; Okami, N.; Sakata, H.; Kim, G.S.; Narasimhan, P.; Chan, P.H. NADPH oxidase mediates striatal neuronal injury after transient global cerebral ischemia. J. Cereb. Blood Flow. Metab. 2011, 31, 868-880. [CrossRef] [PubMed]

94. Liu, H.; Wei, X.; Kong, L.; Liu, X.; Cheng, L.; Yan, S.; Zhang, X.; Chen, L. Nod2 is involved in the inflammatory response after cerebral ischemia-reperfusion injury and triggers NADPH oxidase 2-derived reactive oxygen species. Int. J. Biol. Sci. 2015, 11, 525-535. [CrossRef] [PubMed]

95. De Silva, T.M.; Brait, V.H.; Drummond, G.R.; Sobey, C.G.; Miller, A.A. Nox2 oxidase activity accounts for the oxidative stress and vasomotor dysfunction in mouse cerebral arteries following ischemic stroke. PLoS ONE 2011, 6, e28393. [CrossRef] [PubMed]

96. Radermacher, K.A.; Wingler, K.; Langhauser, F.; Altenhofer, S.; Kleikers, P.; Hermans, J.J.; Hrabe de Angelis, M.; Kleinschnitz, C.; Schmidt, H.H. Neuroprotection after stroke by targeting NOX4 as a source of oxidative stress. Antioxid. Redox. Signal. 2013, 18, 1418-1427. [CrossRef] [PubMed]

97. Raz, L.; Zhang, Q.G.; Zhou, C.F.; Han, D.; Gulati, P.; Yang, L.C.; Yang, F.; Wang, R.M.; Brann, D.W. Role of Rac1 gtpase in NADPH oxidase activation and cognitive impairment following cerebral ischemia in the rat. PLoS ONE 2010, 5, e12606. [CrossRef] [PubMed]

98. Shi, G.X.; Wang, X.R.; Yan, C.Q.; He, T.; Yang, J.W.; Zeng, X.H.; Xu, Q.; Zhu, W.; Du, S.Q.; Liu, C.Z. Acupuncture elicits neuroprotective effect by inhibiting NAPDH oxidase-mediated reactive oxygen species production in cerebral ischaemia. Sci. Rep. 2015, 5, 17981. [CrossRef] [PubMed]

99. Dong, Y.F.; Kataoka, K.; Toyama, K.; Sueta, D.; Koibuchi, N.; Yamamoto, E.; Yata, K.; Tomimoto, H.; Ogawa, H.; Kim-Mitsuyama, S. Attenuation of brain damage and cognitive impairment by direct renin inhibition in mice with chronic cerebral hypoperfusion. Hypertension 2011, 58, 635-642. [CrossRef] [PubMed]

100. Tsukuda, K.; Mogi, M.; Li, J.M.; Iwanami, J.; Min, L.J.; Sakata, A.; Fujita, T.; Iwai, M.; Horiuchi, M. Amelioration of cognitive impairment in the type-2 diabetic mouse by the angiotensin II type-1 receptor blocker candesartan. Hypertension 2007, 50, 1099-1105. [CrossRef] [PubMed]

101. Ostrowski, R.P.; Colohan, A.R.; Zhang, J.H. Neuroprotective effect of hyperbaric oxygen in a rat model of subarachnoid hemorrhage. Acta Neurochir. Suppl. 2006, 96, 188-193. [PubMed]

102. Ostrowski, R.P.; Tang, J.; Zhang, J.H. Hyperbaric oxygen suppresses NADPH oxidase in a rat subarachnoid hemorrhage model. Stroke 2006, 37, 1314-1318. [CrossRef] [PubMed] 
103. Yang, B.; Wang, S.; Yu, S.; Chen, Y.; Li, L.; Zhang, H.; Zhao, Y. C1q/tumor necrosis factor-related protein 3 inhibits oxidative stress during intracerebral hemorrhage via PKA signaling. Brain Res. 2017, 1657, 176-184. [CrossRef] [PubMed]

104. Kim, D.E.; Suh, Y.S.; Lee, M.S.; Kim, K.Y.; Lee, J.H.; Lee, H.S.; Hong, K.W.; Kim, C.D. Vascular NAD(P)H oxidase triggers delayed cerebral vasospasm after subarachnoid hemorrhage in rats. Stroke 2002, 33, 2687-2691. [CrossRef] [PubMed]

105. Zhang, L.; Li, Z.; Feng, D.; Shen, H.; Tian, X.; Li, H.; Wang, Z.; Chen, G. Involvement of Nox2 and Nox4 NADPH oxidases in early brain injury after subarachnoid hemorrhage. Free Radic. Res. 2017, 51, 316-328. [CrossRef] [PubMed]

106. Feng, L.; Chen, Y.; Ding, R.; Fu, Z.; Yang, S.; Deng, X.; Zeng, J. P2X7R blockade prevents NLRP3 inflammasome activation and brain injury in a rat model of intracerebral hemorrhage: Involvement of peroxynitrite. J. Neuroinflamm. 2015, 12, 190. [CrossRef] [PubMed]

107. Toyama, K.; Koibuchi, N.; Uekawa, K.; Hasegawa, Y.; Kataoka, K.; Katayama, T.; Sueta, D.; Ma, M.J.; Nakagawa, T.; Yasuda, O.; et al. Apoptosis signal-regulating kinase 1 is a novel target molecule for cognitive impairment induced by chronic cerebral hypoperfusion. Arterioscler. Thromb. Vasc. Biol. 2014, 34, 616-625. [CrossRef] [PubMed]

108. Nair, D.; Ramesh, V.; Gozal, D. Adverse cognitive effects of high-fat diet in a murine model of sleep apnea are mediated by NADPH oxidase activity. Neuroscience 2012, 227, 361-369. [CrossRef] [PubMed]

109. Dayyat, E.A.; Zhang, S.X.; Wang, Y.; Cheng, Z.J.; Gozal, D. Exogenous erythropoietin administration attenuates intermittent hypoxia-induced cognitive deficits in a murine model of sleep apnea. BMC Neurosci. 2012, 13, 77. [CrossRef] [PubMed]

110. Nair, D.; Dayyat, E.A.; Zhang, S.X.; Wang, Y.; Gozal, D. Intermittent hypoxia-induced cognitive deficits are mediated by nadph oxidase activity in a murine model of sleep apnea. PLoS ONE 2011, 6, e19847. [CrossRef] [PubMed]

111. Hui-guo, L.; Kui, L.; Yan-ning, Z.; Yong-jian, X. Apocynin attenuate spatial learning deficits and oxidative responses to intermittent hypoxia. Sleep Med. 2010, 11, 205-212. [CrossRef] [PubMed]

112. Han, B.H.; Zhou, M.L.; Johnson, A.W.; Singh, I.; Liao, F.; Vellimana, A.K.; Nelson, J.W.; Milner, E.; Cirrito, J.R.; Basak, J.; et al. Contribution of reactive oxygen species to cerebral amyloid angiopathy, vasomotor dysfunction, and microhemorrhage in aged Tg2576 mice. Proc. Natl. Acad. Sci. USA 2015, 112, E881-E890. [CrossRef] [PubMed]

113. Bruce-Keller, A.J.; Gupta, S.; Knight, A.G.; Beckett, T.L.; McMullen, J.M.; Davis, P.R.; Murphy, M.P.; Van Eldik, L.J.; St Clair, D.; Keller, J.N. Cognitive impairment in humanized APPxPS1 mice is linked to A $\beta 1-42$ and NOX activation. Neurobiol. Dis. 2011, 44, 317-326. [CrossRef] [PubMed]

114. Park, L.; Zhou, P.; Pitstick, R.; Capone, C.; Anrather, J.; Norris, E.H.; Younkin, L.; Younkin, S.; Carlson, G.; McEwen, B.S.; et al. Nox2-derived radicals contribute to neurovascular and behavioral dysfunction in mice overexpressing the amyloid precursor protein. Proc. Natl. Acad. Sci. USA 2008, 105, 1347-1352. [CrossRef] [PubMed]

115. Dugan, L.L.; Ali, S.S.; Shekhtman, G.; Roberts, A.J.; Lucero, J.; Quick, K.L.; Behrens, M.M. IL-6 mediated degeneration of forebrain GABAergic interneurons and cognitive impairment in aged mice through activation of neuronal NADPH oxidase. PLoS ONE 2009, 4, e5518. [CrossRef] [PubMed]

116. Chandran, R.; Kim, T.; Mehta, S.L.; Udho, E.; Chanana, V.; Cengiz, P.; Kim, H.; Kim, C.; Vemuganti, R. A combination antioxidant therapy to inhibit NOX2 and activate Nrf2 decreases secondary brain damage and improves functional recovery after traumatic brain injury. J. Cereb. Blood Flow. Metab. 2017, 271678X17738701. [CrossRef] [PubMed]

117. Ferreira, A.P.; Rodrigues, F.S.; Della-Pace, I.D.; Mota, B.C.; Oliveira, S.M.; de Campos Velho Gewehr, C.; Bobinski, F.; de Oliveira, C.V.; Brum, J.S.; Oliveira, M.S.; et al. HOE-140, an antagonist of B2 receptor, protects against memory deficits and brain damage induced by moderate lateral fluid percussion injury in mice. Psychopharmacology 2014, 231, 1935-1948. [CrossRef] [PubMed]

118. Ferreira, A.P.; Rodrigues, F.S.; Della-Pace, I.D.; Mota, B.C.; Oliveira, S.M.; Velho Gewehr Cde, C.; Bobinski, F.; de Oliveira, C.V.; Brum, J.S.; Oliveira, M.S.; et al. The effect of NADPH-oxidase inhibitor apocynin on cognitive impairment induced by moderate lateral fluid percussion injury: Role of inflammatory and oxidative brain damage. Neurochem. Int. 2013, 63, 583-593. [CrossRef] [PubMed] 
119. Sun, X.R.; Zhang, H.; Zhao, H.T.; Ji, M.H.; Li, H.H.; Wu, J.; Li, K.Y.; Yang, J.J. Amelioration of oxidative stress-induced phenotype loss of parvalbumin interneurons might contribute to the beneficial effects of environmental enrichment in a rat model of post-traumatic stress disorder. Behav. Brain Res. 2016, 312, 84-92. [CrossRef] [PubMed]

120. Di Filippo, M.; de Iure, A.; Giampa, C.; Chiasserini, D.; Tozzi, A.; Orvietani, P.L.; Ghiglieri, V.; Tantucci, M.; Durante, V.; Quiroga-Varela, A.; et al. Persistent activation of microglia and NADPH drive hippocampal dysfunction in experimental multiple sclerosis. Sci. Rep. 2016, 6, 20926. [CrossRef] [PubMed]

121. Ding, S.; Yang, J.; Liu, L.; Ye, Y.; Wang, X.; Hu, J.; Chen, B.; Zhuge, Q. Elevated dopamine induces minimal hepatic encephalopathy by activation of astrocytic nadph oxidase and astrocytic protein tyrosine nitration. Int. J. Biochem. Cell. Biol. 2014, 55, 252-263. [CrossRef] [PubMed]

122. Ji, M.H.; Qiu, L.L.; Tang, H.; Ju, L.S.; Sun, X.R.; Zhang, H.; Jia, M.; Zuo, Z.Y.; Shen, J.C.; Yang, J.J. Sepsis-induced selective parvalbumin interneuron phenotype loss and cognitive impairments may be mediated by NADPH oxidase 2 activation in mice. J. Neuroinflamm. 2015, 12, 182. [CrossRef] [PubMed]

123. Hernandes, M.S.; D'Avila, J.C.; Trevelin, S.C.; Reis, P.A.; Kinjo, E.R.; Lopes, L.R.; Castro-Faria-Neto, H.C.; Cunha, F.Q.; Britto, L.R.; Bozza, F.A. The role of Nox2-derived ros in the development of cognitive impairment after sepsis. J. Neuroinflamm. 2014, 11, 36. [CrossRef] [PubMed]

124. Won, S.J.; Yoo, B.H.; Kauppinen, T.M.; Choi, B.Y.; Kim, J.H.; Jang, B.G.; Lee, M.W.; Sohn, M.; Liu, J.; Swanson, R.A.; et al. Recurrent/moderate hypoglycemia induces hippocampal dendritic injury, microglial activation, and cognitive impairment in diabetic rats. J. Neuroinflamm. 2012, 9, 182. [CrossRef] [PubMed]

125. Sharma, B.; Singh, N. Pharmacological inhibition of inducible nitric oxide synthase (iNOS) and nicotinamide adenine dinucleotide phosphate (NADPH) oxidase, convalesce behavior and biochemistry of hypertension induced vascular dementia in rats. Pharmacol. Biochem. Behav. 2013, 103, 821-830. [CrossRef] [PubMed]

126. Ansari, M.A.; Scheff, S.W. NADPH-oxidase activation and cognition in alzheimer disease progression. Free Radic. Biol. Med. 2011, 51, 171-178. [CrossRef] [PubMed]

127. Bruce-Keller, A.J.; Gupta, S.; Parrino, T.E.; Knight, A.G.; Ebenezer, P.J.; Weidner, A.M.; LeVine, H.; Keller, J.N.; Markesbery, W.R. NOX activity is increased in mild cognitive impairment. Antioxid. Redox. Signal. 2010, 12, 1371-1382. [CrossRef] [PubMed]

128. Wang, X.L.; Iwanami, J.; Min, L.J.; Tsukuda, K.; Nakaoka, H.; Bai, H.Y.; Shan, B.S.; Kan-No, H.; Kukida, M.; Chisaka, T.; et al. Deficiency of angiotensin-converting enzyme 2 causes deterioration of cognitive function. NPJ Aging Mech. Dis. 2016, 2, 16024. [CrossRef] [PubMed]

129. Inaba, S.; Iwai, M.; Furuno, M.; Tomono, Y.; Kanno, H.; Senba, I.; Okayama, H.; Mogi, M.; Higaki, J.; Horiuchi, M. Continuous activation of renin-angiotensin system impairs cognitive function in renin/angiotensinogen transgenic mice. Hypertension 2009, 53, 356-362. [CrossRef] [PubMed]

130. Sharma, B.; Singh, N. Pitavastatin and $4^{\prime}$-hydroxy-3'-methoxyacetophenone (HMAP) reduce cognitive dysfunction in vascular dementia during experimental diabetes. Curr. Neurovasc. Res. 2010, 7, 180-191. [CrossRef] [PubMed]

131. Lu, J.; Wu, D.M.; Zheng, Y.L.; Hu, B.; Cheng, W.; Zhang, Z.F. Purple sweet potato color attenuates domoic acid-induced cognitive deficits by promoting estrogen receptor- $\alpha$-mediated mitochondrial biogenesis signaling in mice. Free Radic. Biol. Med. 2012, 52, 646-659. [CrossRef] [PubMed]

132. Nair, D.; Zhang, S.X.; Ramesh, V.; Hakim, F.; Kaushal, N.; Wang, Y.; Gozal, D. Sleep fragmentation induces cognitive deficits via nicotinamide adenine dinucleotide phosphate oxidase-dependent pathways in mouse. Am. J. Respir. Crit. Care. Med. 2011, 184, 1305-1312. [CrossRef] [PubMed]

133. Qiu, L.L.; Luo, D.; Zhang, H.; Shi, Y.S.; Li, Y.J.; Wu, D.; Chen, J.; Ji, M.H.; Yang, J.J. Nox-2-mediated phenotype loss of hippocampal parvalbumin interneurons might contribute to postoperative cognitive decline in aging mice. Front. Aging Neurosci. 2016, 8, 234. [CrossRef] [PubMed]

134. Qiu, L.L.; Ji, M.H.; Zhang, H.; Yang, J.J.; Sun, X.R.; Tang, H.; Wang, J.; Liu, W.X.; Yang, J.J. NADPH oxidase 2-derived reactive oxygen species in the hippocampus might contribute to microglial activation in postoperative cognitive dysfunction in aged mice. Brain Behav. Immun. 2016, 51, 109-118. [CrossRef] [PubMed]

135. Zhang, H.; Sun, X.R.; Wang, J.; Zhang, Z.Z.; Zhao, H.T.; Li, H.H.; Ji, M.H.; Li, K.Y.; Yang, J.J. Reactive oxygen species-mediated loss of phenotype of parvalbumin interneurons contributes to long-term cognitive impairments after repeated neonatal ketamine exposures. Neurotox. Res. 2016, 30, 593-605. [CrossRef] [PubMed] 
136. Sun, Z.; Satomoto, M.; Adachi, Y.U.; Kinoshita, H.; Makita, K. Inhibiting nadph oxidase protects against long-term memory impairment induced by neonatal sevoflurane exposure in mice. Br. J. Anaesth. 2016, 117, 80-86. [CrossRef] [PubMed]

137. Kishida, K.T.; Hoeffer, C.A.; Hu, D.; Pao, M.; Holland, S.M.; Klann, E. Synaptic plasticity deficits and mild memory impairments in mouse models of chronic granulomatous disease. Mol. Cell. Biol. 2006, 26, 5908-5920. [CrossRef] [PubMed]

138. Walton, J.C.; Selvakumar, B.; Weil, Z.M.; Snyder, S.H.; Nelson, R.J. Neuronal nitric oxide synthase and NADPH oxidase interact to affect cognitive, affective, and social behaviors in mice. Behav. Brain Res. 2013, 256, 320-327. [CrossRef] [PubMed] 